\title{
Squandering Opportunities: Sri Lanka's Overlooked Development Potential
}

\author{
Nihal Perera
}

Let me begin by asking:

\begin{abstract}
If people have to spend hours in busses, if the bus plays loud and annoying music and does not stop for the passengers to get off, if women/girls have to constantly defend themselves from men/boys on busses and in public spaces and are restricted to particular places and times, if men are afraid to go out at particular times and visit certain places, if people are stressed out, constantly struggle to get before the other, and not reluctant to look down upon others due to ethnicity, caste, class, sex, or political allegiance, if parents have to be vigilant of their kids, if citizens bribe to get ordinary work done, if education requires tuition classes and spending the whole day, if getting the doctors attention requires paying, and if national leaders get enormously rich after they assume public office, is this development? Would building dams and highways, cleansing areas of the poor and the powerless, beautifying and gentrifying urban neighborhoods, and/or building megapolis develop such society? Who benefit from such projects?
\end{abstract}

The last government (2010-2015) spent huge undisclosed amounts of money on highway and road construction. The purpose of highways is to transport goods and people. Yet road-building projects have been of little help to ordinary people. Despite the last government's heavy investment on road infrastructure, from building highways to concreting niyaras, ${ }^{i}$ Sri Lanka is the only country that I know of where bus drivers hardly think that they have to stop the bus for passengers to get on and off. ${ }^{\text {ii }}$ Busses are very slow, mostly uncomfortable, and not womenfriendly. Child- and disable-friendliness is long ways away. This exposes a colossal gap between the needs of ordinary people and what the projects have provided. Yet there is hardly a substantive critic of this issue. This highlights the curious case of missing expert.

The focus on infrastructure and the physical environment, in regard to development, can be traced back to 1977. From Mahaweli to Megapolis, ${ }^{\text {iii }}$ Sri Lankan governments have equated national development to infrastructure building and monumentalism. The focus has been on the physical rather than the social, (See Perera 2010) There seems a big mismatch between development policies, projects, and people's aspirations. The former have seemingly failed to fulfill their own promises as relayed by experts and politicians and/or to take people to the promised land projected by the development discourse. Increasingly, development has sidelined the goal of improving the quality of life and the life journeys of ordinary people are not even acknowledged. People themselves have lost track of their own worth; not many people even notice that the bus does not stop for them. This calls for further investigation of the state of development in Sri Lanka and its trajectory. This is the intent of this article.

Ceylon was incorporated into the periphery of the European world-economy in the 19th century. (Perera 1999) Andre Gunder Frank (1979) demonstrates that the same process that develops core states [of the world-economy] underdevelops the states in the periphery. As elaborated below, the leaders of independent Ceylon continued this economic model set up for the colony; the influential experts propagates this model of underdevelopment.

The political leaders were more savvy in the area of politics. They declined to take part in the Cold War, constructed a non-aligned 
position, and took part in the creation of the Non-Aligned Movement. They also severed the vestiges of colonialism in 1972, (Perera 1999) and changed the name to Sri Lanka. Yet they did not question the borrowed development model and the issues caused by it, nor was the continued cultural colonialism questioned. National leaders, with the help of local experts who also grew up within the same post-colonial political-economy, constructed the dependent, undeveloped state of Sri Lanka that we know.

Conspicuously absent from contemporary development thinking is ordinary people. After seven decades of development and an expansion of the middle-class over a couple of decades, there are more poor people in Sri Lanka today than at independence. (Yapa 1998) Most parents do not believe that their children's educational needs are met within the school system. Almost every child who can afford tuition classes attend them. Most patients do not believe that they can get good service at public hospitals. They channel government doctors many of whom sound like businessmen. ${ }^{\text {iv }}$ The state of development of Sri Lanka has definitely declined since independence, most clearly from the 1970s. While more people have elevated themselves to the middle-class, the quality of life of many has declined due to the same processes.

Despite the beautification of select cities and providing more recreational spaces, half of the urban population lives in "underserved settlements" (Fernando 2015). During the last few decades, the GNP increased due to mega construction projects. The last government even claimed that Sri Lanka has become a middle-income country. However, this has not caused any significant improvement in the quality of life of ordinary citizens, particularly the poor. The gap between the expectations and results of development projects and programs is compounded by another significant gap between the objectives of the state's development projects and what the people need and want.

Hence, it is time to dig deep and ask serious questions about development: Is it measured by the input or by the outcomes? Is the billions of dollars spent, the increases in the GNP, the grandeur of highways, or the beauty of cities that matters? Should development not cater to the wellbeing of people? Should wellbeing include how quickly, safely, and efficiently people, including women, children, the elderly, and the disabled can accomplish their daily activities and cultural practices? How could we measure good education, health care, and other services?

The disconnect between development goals and strategies is caused by the experts lack of knowledge of development and the state manipulating knowledge to serve capital and private interests of the powerful. Jan Nederven Pieterse (2001) demonstrates how the development discourse has changed and diversified over time, at times acknowledging, responding, and co-opting the critiques. In practice, governments take advise from "experts." The "influential experts" who are heard by the authorities and significant institutions have significant power to affect development related decisions. They too have followed the hegemonic model with minor adaptations and served the underdevelopment of the nation.

Knowledge or lack thereof, is central to the underdevelopment of Sri Lanka. The development of Sri Lanka requires the acknowledgement of Sri Lanka's strengths, viewed from within Sri Lanka, using and validating Sri Lankan interpretive tools and worldviews. (cf. Perera and Tang 2013) The European world-economy (Wallerstein 1979; 2004) into which Ceylon was incorporated in the mid-nineteenth century, was not grounded in the colony, nor was it grounded in independent Sri Lanka by its politicians and experts. As elaborated in the introduction of this special issue, national economic policies represent the voluntary adoption of a deficit model by the nation.

As evident below, the lack of development is largely caused by the lack and inaptness of the knowledge employed to change the developmental predicament of Sri Lanka. Mainstream knowledge is Eurocentric. The analysts, whether politicians or experts, use large-scale and abstract data, foreign analytical methods, and approach the issues from external vantage points. (See Perera and 
Tang 2013) This gap is the focus of this article.

Scholars and specialists largely view development from global perspectives that are considered superior to "local" perspectives. According to the dominant view, the world is made up of nation-states, not people, groups, or regions, that follow a single economicallydefined development path, but are at different points in this historical trajectory. (Rostow 1960) This perspective is hardly national, but supranational, looking at nations that are considered homogenous units. As this knowledge is not grounded: neither developed in the particular nation nor adapted to it, it is easily subject to manipulation by power holders, especially politicians and influential experts not intentionally. (Goonatilleke 1984)

This paper examines development at a national scale, but from within Sri Lanka, employing an inside-out perspective, and using the threshold between the national and international to look outwards. Analytically, I employ well-known dependency and worldsystems perspectives (Frank 1979; Pieterse 2001; Wallerstein 1979), but critically to locate Sri Lanka within a capitalist worldeconomy and its trajectory. I will shift the focus from imposing development or underdevelopment from outside to the national rulers accepting and reproducing these. I use postcolonial theory, discourse analysis, and cultural studies in general to critically understand the role played (or not) by national leaders and experts.

In addition to shifting the vantage point of inquiry, I do not view the nation as a victim of development trajectories imposed on them. The national leaders do employ their agency in shaping the development trajectory. They should consciously use this agency and take responsibility for it. According to this perspective, while large structures such as the capitalist world-economy attempts to subject the nations, national leaders and local experts have tried to organize the national economy in ways it can survive in the larger capitalist world-economy, or develop the way they can.

Moreover, the influential experts play a crucial role in developing the positions the state takes. In addition, the expert knowledge, now also disseminated through the television, is key to the hegemony the (under)development idea gains among the citizens. In Sri Lanka, the politicians have a much larger power to convince people, but would be lost without the backing of these experts.

This three-prong intellectual strategy enables the author to acknowledge the role played by national leaders and influential experts not acknowledged in outside-in structural analysis. It also enables me to examine potential room for development and intervention from the side of nation, particularly by the state and experts.

The analysis reveals that there were three major "development opportunities" and the Sri Lankan governments squandered all. By "development opportunities" I refer to crucial political-economic opportunities the national leaders had to (re)negotiate the nation's position within the (global) political-economy, at least the nature of dependency. The first was at independence when the first national government accepted the Western model of development as opposed to continuing with the emergent "Sri Lankan model."

Second was in the late-1970s when capitalism was in crisis and Ronald Reagan, Margaret Thatcher, and Deng Xiao Ping were struggling to reproduce the system. As they produced neoliberalism to save the world-economy, the 1977-government accepted structural adjustments, reproducing Sri Lanka's Third World status within this structure. The third time is now: In the current transition of the capitalist world-economy, during this conjuncture China and India attempt to establish their dominance, the last government constructed an economic and political dependency on China. The opportunity is still available to the current government, but how it will deal with the opportunity is not evident. This paper focuses on the three squandered opportunities.

Instead of exploring these chronologically, I will examine the themes that emerge from the instances: The opportunities within the worldeconomy, the failures of the national government to recognize the strength of local models and/or emergences, and the current transformation of the capitalist world-system. 
It will demonstrate that the national leaders and experts have failed to understand the development discourse in which they take part, the opportunities that arise within the world-economy, the development potential within the nation, and the opportunities the combination of these provide for the nation. I identify the mentality of scarcity of the leaders and influential experts as a main cause for overlooking these opportunities, a condition elaborated in the final essay of this special issue.

\section{Blindness to Strengths: Adopting a Deficit Model}

At political independence in 1948, the Ceylonese had a high quality of life. It is said to be envied by the leaders of Singapore and South Korea. The mainstream development discourse speaks highly of Kerala and Sri Lanka. They questioned the mainstream model of development: According to the paradigm proposed by the world-leaders, especially the USA, the development of the national economy (GNP) is the means to achieving the high quality of life experienced in the West. Yet Sri Lanka and Kerala had high social indicators such as life expectancy and literacy, despite low GNPs. The gap between the rich and the poor was also small. This was reconfirmed by Sen (1999) in his work on Development as Freedom which earned him a Nobel Prize. For the British too, Ceylon was a model post-colony and angel of democracy.

Yet neither the Ceylonese rulers nor the national experts saw local strengths. At independence, the national leaders had the option of further developing and enhancing the emergent society. Instead of leading the nation out of dependent economic structures developed under colonialism, national leaders opted to reproduce the colonial subjectivity and dependency within the world-economy reformulated under the US hegemony. If the leaders and/or experts saw the local strengths, they did not see the potential and/or were incapable of justifying and/or building policies to enhance them. Instead of building on ground conditions, they transformed the ground conditions to fit the borrowed concept, a practice that still continues. All three major instances of squandering development opportunities, discussed in this paper, indicate this blindness.

What the leaders and experts saw was the development deficit. Development propagated by the Western core states and the US leadership is a deficit model in which the subject-nations believe that they are poor(er), inferior, lack development, and do not have what it needs to develop. (cf. Escobar 1995) This perspective hid from them the relatively high quality of life of the citizens at independence and possibility of enhancing it.

In order to achieve the development the West had achieved, the nation needs capital, technology, and the knowhow. The only source of these are core countries that have achieved development; lately, also the proxies such as China. Hence development is a dependency model; the nations have to depend on the West for resources and knowledge. It is this imported knowledge that provided experts with a Third World mentality, making them overlook all three opportunities discussed in this paper and, in fact, work hard to develop the nation, but on the reverse gear.

The discourse has made the non-Western states not only poor (deficient), but also dependent. The emphasis here is on the consciousness. The leaders and experts developed a subservient consciousness, accepting that the nation lacks development (of Western style). Hence, development is more cultural and a (social) power relation than economic; even today, it is hard for development specialists to see this logic. ${ }^{\mathrm{v}}$ Enabling the discourse to construct underdevelopment, the leaders and experts transformed Ceylon into a Third World country. Development projects, whether highways or Megapolis, perpetuate and enhance this dependency.

"National development" was on Ceylonese political leaders' radars for decades before independence. Despite the push for industrialization, especially by the socialists (Sama Samajists) and the somewhat positive responses by select governments led by the Sri Lanka Freedom Party, the post-colonial state has not been able to transform the Sri Lankan economy in ways that would improve capital 
accumulation within the nation. This occurs in the core states. In this, the national leaders squandered an opportunity to question the imported and/or imposed model.

As the hegemonic development model is well known, and briefly mapped out in the introduction, I will not repeat it here. However, a critical recap of a few major characteristics can help us better contextualize the predicament it created:

First, mainstream development that responds to a development deficit takes the form of emulation. Yet it is impossible for other states to catch up with the West as it is a moving target. Most Western states are now postindustrial, consumerist, and a large number of cities in these are deindustrialized, declined, and distressed. (See Dotson and Perera, this issue) This is perhaps not what developing countries desire. Yet the "ideal" has not changed for developing nations.

Moreover, this foreign idea cannot be fully implemented in non-Western states. Homi Bhabha (1994) demonstrates that mimicry is impossible; it produces alternatives. In regard to space and urban development, I have also demonstrated elsewhere (Perera 2016) that almost all subjects transform given spaces, even if s/he voluntarily becomes a subject. The changes caused in the notion of development in its adoption can provide insights into possible paths of development for the country.

Second, the dominant notion of development is a universalization of the specific history of the West that was able to develop through industrial revolutions in a colonial context. As presented in Walt Rostow's (1960) "noncommunist manifesto," this history is represented as the natural trajectory of all nations; every nation traverses the same historical path that includes a takeoff propelled by an industrial revolution. This history of the West is unrepeatable: As discussed in the introduction, Frank (1979) demonstrates that the periphery is in a structural bind; when the core states develop the rest underdevelops.

The units of analysis do not match either: Western states that brag to have staged industrial revolutions were not nation states; they were imperial metropoles that had vast colonies to exploit and to draw large quantities of raw materials and other resources. The classification of developed states is biased too: When the GNPs of Communist and Middle Eastern states became quite high, they were so categorized; not as developed countries.

Third, development programs and projects added more layers of dependency for developing countries. The development discourse camouflaged the exploitation of the West, making the states in the periphery believe that they are victims of their own history. In this context, the core states became benevolent providers, transforming underdeveloped states into passive recipients of development. Developing countries become more dependent on such aid and knowledge from core states.

Fourth, aid and loans come with conditions. As I have discussed elsewhere in regard to the Mahaweli project, (Perera, 2010) development projects came with conditions that favor the donor country or the institution.

As development projects were not grounded, politicians and experts were better positioned than citizens to find ways to benefit from them. Development became a fertile ground for corruption, particularly for commissions, bribes, perks, and favors for politicians and experts in underdeveloped countries, which includes high paying jobs, consultancies, and foreign trips. From Gamini Dissanayake to Mahinda Rajapaksa, politicians used mega projects, especially the massive spectacles they produce to build political capital. They also transformed development projects into business ventures and personal capital, and used for material and financial gains. In this, the poor in Sri Lanka were further impoverished. Megapolis is yet to provide an alternative.

Fifth, by the 1960s, development in the Third World became integral to West's existence. By then an international development complex involving Western states, banks, and businesses had fully grown. The development machine also participated by politicians and experts from the Third World had become monstrous; it needed to be maintained through 
pushing development on Third World states. This is evident in the use of economic pressure and hit men to impose development. (Perkins 2004)

Sixth, the transferring of knowledge, technology, and equipment is political; they come with strings attached and in ideological wrappers, bearing the worldviews of the West where the discourse was produced. Within the context of (Western) enlightenment and science, and downplaying the cultural politics in it, development is assumed to be politically neutral and can be exported to any place on earth. The discourse is easily applied by the experts from the core and, to a degree, by the Westernized experts elsewhere. These experts who work hard for the underdevelopment of their own nations develop a disability to see and appreciate local strengths; especially from local perspectives.

Seventh, the model is both flawed and failed. Political-economists have long highlighted the lack of redistribution of resources. Sen (1999) too highlights that, in practice, the means of development have overshadowed the ends. Although the goal is to achieve a higher quality of life for people, the focus on higher GNPs and growth rates have privileged affluent and rich ways of life. In this practice, social values are subjected to economic calculations, jamming the process of "development."

Eighth, as it is not grounded, the development knowledge and discourse is easily manipulated by politicians, businesses, and experts in the periphery. (cf. Goonatilleke 1984) Hence, this dependent structure benefits a small group of politicians and experts in the recipient state.

In sum, the dominant model of development is flawed. As demonstrated from Frank to Escobar, development within this model is impossible and the model has failed to deliver. The practice of it has constructed a dominantdependent relationship between the Western core states and other nations in the form of core-periphery. It has been good business for the development industry based in core Western states and participated by "experts" from the periphery in the form of politicians, economists, development specialists, policy makers, and planners. It is this model that the Sri Lankan leaders and experts embraced at independence and continued to subscribe. Although the approach to development changed in the late 1970s, as demonstrated below, the development ideology and the structure continued.

In so doing, Sri Lankan political leaders and experts not only overlooked the state of development of Ceylon at independence, but also failed to produce any significant grounded-alternatives. N.M. Perera, the Finance Minister of the 1970-government, questioned the hegemonic development discourse. Yet he adopted the import substitution and industrialization (ISI) model that was developed by scholars of dependency school in Latin America, and combined it with a broader distribution of resources. This was not well received; he even lost his parliamentary seat that he won since 1935 .

While some data such as the size of the middle class may be greater, overall above policies have impoverished Sri Lanka. As mentioned above, there are more poor people in Sri Lanka today than at independence. Even the people who claim to be more prosperous (i.e., the expanding middle class) cannot show social gains built upon the monetary gains. Gains in education and health are nominal: Parents hardly believe that their children's educational needs can be met within the school system anymore. The politicaleconomy has devalued college education, especially critical knowledge. Every child of parents who could afford tuition classes attend these. Also, most patients do not believe that they can get good service at hospitals; they use channeled services to induce to doctor to provide adequate service. Most alarming is the suicide rate. Whatever the cause is, Sri Lanka is the third (almost the second) in the world (List of Countries by Suicide, 2016). The state of development of Sri Lanka has definitely declined since independence, most clearly from the 1980s.

The primary cause of this national vision is the identity of its leaders and experts: their own mentality of deficit cultivated within the (post) colonial system. Influential experts have been unable to see alternative paths; if anyone of 
them proposed, the national leaders did not hear them. The Marxist leaders too embraced the same path of development, but with the equitable distribution of resources. The furthest they got was when the adoption of the ISI policy, but after the model has begun signs of failure in Latin America.

It is important to note the lack of the "national" in Sri Lanka. Beginning from the first government depriving the estate workers of citizenship, national governments have been involved in sectarian politics. President J.R. Jayawardena stripping political rights of his predecessor Sirima Bandaranaike reveals this lack of national thought. The former saw the latter as a political opponent who should be stripped of power rather than the national leader he succeeded. While the magnitude of action maybe unique, the type of thinking is very common. Rajapaksa who claims to have ended the separatist war accused of the Tamils of voting for his opponent, thus pushing them to another camp. The only major exception is the Samasamaja Party that built the nation as it led the independence struggle. (Perera 1999)

The discourse and structure of development created their own subjects: It turned economists into mathematicians, social scientists into serial thinkers, and generated development professionals who work for institutions such as the World Bank and the UNO on development projects and universities which produces subjects of these discourses. Ironically, these experts earn their livelihood by reinforcing, socializing, and justifying the process of underdevelopment, under the name of development. How different the Megapolis project is yet to be seen, but the experts seem to silence the critics more by defaming critic than engaging the point.

The critical discourses have left some influential ideas, particularly the need for redistributing of resources, largely meaning the incomes and life/social opportunities should be more evenly spread across the population of a country. Also the end of the Cold War had dismantled the duality between wealth production and redistribution (i.e., American and Soviet models). It is well accepted today that wealth production and the distribution of incomes can occur at the same time, although the capitalists struggle to appropriate the largest possible proportion of the wealth production. Yet, with the expansion of the middle classes under neoliberalism, for many scholars and practitioners, poverty is on the way out and there is no need to pay special attention to it (Nandy 2004). This puts the poor in a dire state.

There are also studies and theories that acknowledge and focus on people's agency, their capacity, and the their own development processes. (Boggs 2012; Esteva 1992; Hamdi 2004; Perera 2016; Sen 1999) These scholars use people as the unit of analysis, deconstructing the nation; they attempt to capture the local strengths.

\section{Overlooking the Systemic Crisis:

Adopting Structural Adjustments,
Supporting Neoliberalism

A substantial opportunity to change the developmental status of the nation emerged in the 1970s-80s. There is ample evidence to suggest that the capitalist world-economy was in crisis in the 1970s. It was reproduced through the development of what was later called neo-liberalism. (Harvey 2005) Very few states capitalized on the moment to develop alternatives or negotiate the developmental status. Instead, Third World governments and experts contributed to the rebuilding of the world-economy and its structures of exploitation, along with their own dependencies and underdevelopment. Sri Lanka was no different.

The hegemon was not only troubled at the turn of the 1970s (1968-72), but also its hegemony began to decline. This became evident in various revolts across the world, including the Tet Offensive against the US military in Vietnam and the Organization of Petroleum Exporting Countries (OPEC) opting to determine the prices and the amount of oil released to the market. The global structures developed under the US leadership after the War went into disarray and the leading nations began restructuring these. Reagan, Thatcher, and Deng led and directed the rejuvenation of the capitalist world-economy. The main strategy adopted by the core states to restructure the periphery was structural adjustments, carried out through the 
International Monetary Fund and the World Bank.

This was not the only option open to the states in the periphery. As the development of individual nations is prevented by the structural relationships between core and peripheral states, (Frank 1979) the (re)negotiation of the position of peripheral states within the world-economy is possible only when the structure, particularly the links between the core and the periphery, is weak. The 1970s opened up such opportunity. The four tigers (i.e., Hong Kong, Korea, Singapore, and Taiwan) made use of this room to move from the periphery of the capitalist world economy to the semi-periphery. (Wallerstein's 1979)

The opportunity to adopt a different development-model or to negotiate the position within the world-economy was open to Sri Lanka and other states as well. In adopting structural adjustments, the periphery at large collaborated with the core states in building neoliberalism. This reproduced the former dominant-dependent structure, with particular changes appropriate for the time.

Adopting structural adjustments, the 1977government in Sri Lanka joined the bandwagon of Third World states. Contributing to rebuild dependency highlights the blindness of the political leaders and influential experts to the opportunity that existed. The government brought the county's subordinate position to a different plane and enjoyed foreign loans and mega projects, causing further dependency and promising people a Singapore.

The national economy grew much faster in the 1980s and 90s, but the gap between the rich and the poor increased. In regard to the Gene coefficient which indicate the gap between the rich and the poor, Sri Lanka was in 40-45 range in 2014. (List of countries by income, 2016) It was beyond the experts to think of a method that could both grow the national economy and improve the living standards of the larger populace. All welfare was not eradicated; this shows the strength of what the socialists have established. Hence, structural adjustments were not complete. (Goonatileke 1984)

The mega projects from the Jayawardena period (1977-1989) to Ranil Wickramasinghe's (2015-current) belong to this combination of neoliberalism and structural adjustments, with some remnants of "welfarism." Yet from Mahaweli to Megapolis, development projects have increasingly become spectacles such as dams, canals, and highways. The past decade saw the spending of colossal sums of money to build spectacles like the Nelum Kuluna (Lotus Column), Nelum Pokuna (Lotus Pond), and the spaces of consumption in Colombo built by refurbishing select old colonial buildings such as the Race Course, Independence Arcade, and newly-built Diyatha Uyana. They consumed huge sums of money, made many politicians and experts rich, for very little payback to the national economy. This is the Third World version of what Susan Strange (1986) calls Casino Capitalism in the core.

\section{Subjecting to Power: Mega Confusion}

That is the past, but the most important opportunity is here and now. Yet there are no sings of change.

The capitalist world-economy is in a more radical transition. The little we know informs us that we are experiencing either the demise of the capitalist world-economy or the rise of another hegemon that will restore, restructure, and bring new order to it. Most analysts believe that China and/or India will be the next leader/power.

If we take this option, once a state establishes its hegemony and restructures the system, the structure could last for a century. It will be difficult to renegotiate the position within that order as long as the system is strong. The time to negotiate is now, when the structures are being formed.

The transition period is marked by competition and negotiations between potential hegemons, the extant power, the USA, and also influential states such as Russia. The core itself is in flux and the structural linkages such as commodity chains 
and channels of capital accumulation are weak. For less powerful states, the current conjuncture has opened up a rare opportunity to negotiate their positions within the emerging world-order and to take part in shaping it.

This is certainly not the time for Sri Lanka to act like a subordinate state, a poor country, or get into a petite fight and lose opportunities. The previous government, from time to time, attacked US imperialism. USA is the fading hegemon and such protests and fights have very little political and/or economic value for the future.

It was a grave mistake for the previous government to construct a subordinate position vis-a-vis a potential hegemon, China. If China becomes the leader, this dependent and subordinate relationship will become a part of the new world order and may last a century. A better option is to push for the best possible political-economy and to negotiate and/or construct the best position within it for the nation. This requires knowledge, persuasiveness, and diplomacy.

It is also time to rethink about borrowing to build infrastructure, whether highways or Megapolis, and developing subordinate relationships with China, India, and/or other potential leaders. Many of the mega projects built across the world in the past, whether large dams or big cities, were found flawed by the very same agencies that propagated and sustained themselves through these projects. While every nation desired dams in the 1950s through the 1980s, huge issues such as salination, malaria, silt formation, lack of water during droughts, and not being able to control floods came to dominate the discussion by the 1990s.

The efficiency of such projects has proven to be low. Development is a power relation within which a particular agency could advise a community, society, or a nation, sustain its own livelihood, and learn or declare that it was not that accurate or that effective without being penalized. This is precisely the power that has been developed, at the small scale, by local experts who propagate mega projects for their own nation.
Infrastructure building is an old practice that was highly recognized. It is being normalized through politics that argues for and against highway projects and Megapolis, as many in the middle have found ways to earn money. These projects cause very little development at people's level; maybe regression in some ways. The busses not stopping for passengers is a recent culture that began after the privatization of busses.

To be increasingly clear, building infrastructure without production is consumerism that serves particular categories of people for a short time, but with the hope that it serves more economic activities. The maintenance of such infrastructure is possibly beyond the fiscal capacity of the Sri Lankan state. While President Ranasinghe Premadasa built many highways with foreign loans, Rajapaksa borrowed more to repair and upgrade them; he also built a few stretches of highways. It is hard to stop development projects not because of the poor, but the growth machine needs them to survive. Projects such as Megapolis operate at large scales that cannot touch people. If it is to help the nation, it should be a part of a thoughtful plan that addresses development at a more decentralized, people's level.

Instead of developing dependency, states such as China and India can be viewed as assets. Sri Lanka can question the intentions and roles of the rising powers, the kind of relationships it needs to build with them, and find ways to negotiate the most favorable position vis-à-vis these states and the global structures they are building.

The governments and select development professionals have been somewhat conscious of this opening and have attempted to transform its location into an asset. Yet, there is hardly any progress to show. This indicates flaws in the understanding and framework. What the public hears from politicians is the promise to transform Sri Lanka into a Singapore or a similar model. This resonates deficit thinking all over, but is now largely focused on Asian cities.

Developing a centrality for Sri Lanka in Asia is plausible, but simply highlighting the geographical advantage will not bring much. 
This advantage needs to be operationalized substantively, before the opportunity passes. The rulers and experts cannot afford to spend resources on projects of low return such as Megapolis. If not, history (local politics and visions) might dispose what geography has proposed. (cf, Braudel 1985)

Being near fast-growing India, which is also a large field of investment and a market, is the most crucial advantage. Sri Lankan Airlines attempted to capitalize on this, but the results are limited. There are many examples that can inspire the building of a grounded development strategy. To name a few, there is a strong similarity between the geographical locations of Hong Kong and Sri Lanka in their geographical and political-economic proximities to China and India. Despite the distance, Singapore has turned itself into a gateway to Asia from the southeast. On the western side, Dubai has established itself as another entryway to Asia and Doha is a close competitor. It is worth thinking about other centralities. National University of Singapore has established itself into a global center of knowledge production and distribution, but Sri Lanka does not even have a university press. India has established itself into a center of cricket, film, and health.

In sum, the national governments have squandered opportunities to negotiate Sri Lanka's status within the world-economy. They have submitted the country to Western domination and exploitation, constructing and reproducing it as a Third World country at each opportunity to do better. Now it is being subjected to emerging powers.

Sri Lanka's underdevelopment was not constructed by core Western states or colonialism alone. A crucial role was played by Sri Lankan political leaders and experts to underdevelop it and/or to maintain its underdevelopment. Now is the time to negotiate some structural impediments. Missing the current opportunity to negotiate the state of development can be detrimental to the nation. It is the time to look for alternatives.

\section{The Need for Grounded Knowledge:}

While there is a multitude of causes for missed opportunities, the most fundamental is the lack of knowledge. National rulers and experts sorely lack an understanding of development opportunities, especially how the capitalist world-economy operates, potential openings for change, and structural constraints to the state's agency. More fundamental is the lack of grounded-knowledge, particularly a sense of nation, a national vision, potential (developmental) paths, and an assessment of the capabilities of the nation and its rulers to take advantage of such opportunities.

Understanding the strengths and weaknesses of the nation requires the building of a knowledge of the global political-economy which attempts to subjugate the nation and maintain its subjectivity; the nation state which attempts to overcome these impositions and attempts to find its own path; and their interactions, both collisions and collusions. The lack of knowledge is further exacerbated, especially since the 1980 s, by the national leaders' and their intellectual aides' focus on political parties, family, and/or individual gains. The politicians increasingly view critical and alternative knowledge as a threat. In this context, the experts are keen in satisfying politicians to grab opportunities for them. Individuals think such opportunities are limited. The individuality and the mentality of scarcity evident in this are detrimental to developing the much-needed knowledge.

Development is expected to benefit the people (i.e., the nationals). According to Sen, (1999: 285) "development should enable people to lead the kind of lives they have reason to value," whether it is supported or not by an increase in the GNP, technical progress, or industrialization. This implies agency: people providing for themselves, within limits, in their own ways, with appropriate external support. This idea is not new to Sri Lanka; For example, in the 1980s, Susil Sirivardana led the development of a national housing policy based on "support systems," for the Million Houses Programme. There are many other good examples; Lankan experts simply need to look within the country, and learn, rather than look outside. Within the nation, the 
external provision of development also represents a deficit model; it disempowers people and underdevelops the country. (See Dissanayake, this issue) Similar to what the international provision of development did to nations, the state provision of development transforms citizens into victims who depend on external help. This is an impediment for people to become self-sufficient and believe in themselves.

As I have demonstrated in People's Spaces, (Perera 2016) people have agency; they conceive and create spaces for their daily activities and cultural practices. They work towards their individual development. They create more life opportunities and spaces than the state and other external providers. The state cannot do what people can do; nor can private businesses, or NGOs. By achieving their life goals, people develop the nation. People are both the main resource and the beneficiary of development. The rise of four tigers taught, healthy, educated, and strong people are the base of national development; not simply the product. (Sen 1999)

It is more effective and efficient for the states to help people empower themselves (i.e., to support people's life journeys by enhancing their capabilities and removing roadblocks that hinder the achievement of their aspirations).
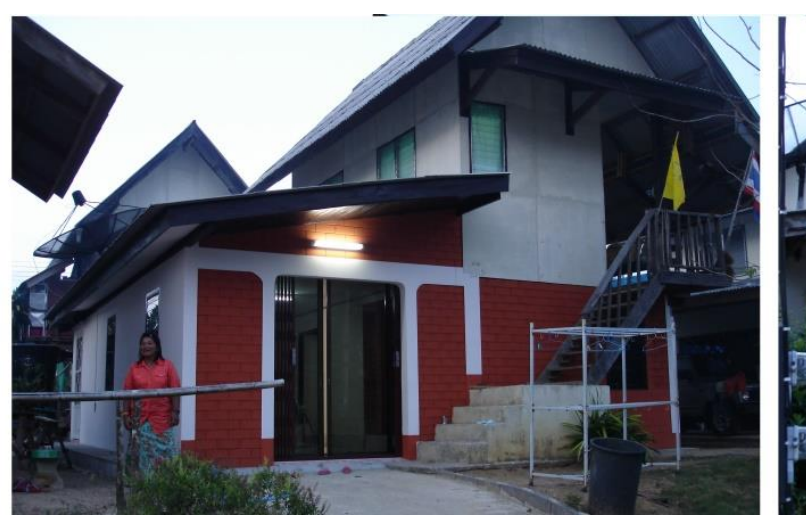

By empowering, I refer to the enhancement of people's capability to achieve their aspirations. For example, providing an effective transportation service is more crucial than building roads; a transportation system has no meaning for passengers if the bus does not stop for them and men harass women.

I wish to emply three post-tsunami recovery projects to highlight the difference between provision and support and their effects on the subjects. I refer to Banda Aceh, Indonesia where 200,000 people died, Hambantota where over 10,000 people died, and Phuket, Thailand where the damage was not so severe. Most money was spent in Aceh. By January 2008, a massive highway was built and some victims had nice-looking houses, but most of them hardly had sewer connections. The five main housing projects in Hambantota District were better managed: The victims live in architect-designed houses with water and electricity, built on government-donated land. This sounds like a middle-class dream come true, but people worked very hard to adapt to the environment, which was alien to them. (Perera 2016) They even built their own kitchens, a primary requirement of a Sri Lankan house. The King's project in Phang Nga was much simpler. The survivors were given a single-room raised on four columns, with a toilet and a large roof. By early-2008, people had built a diverse neighborhood around these strucures. (Figure 1)

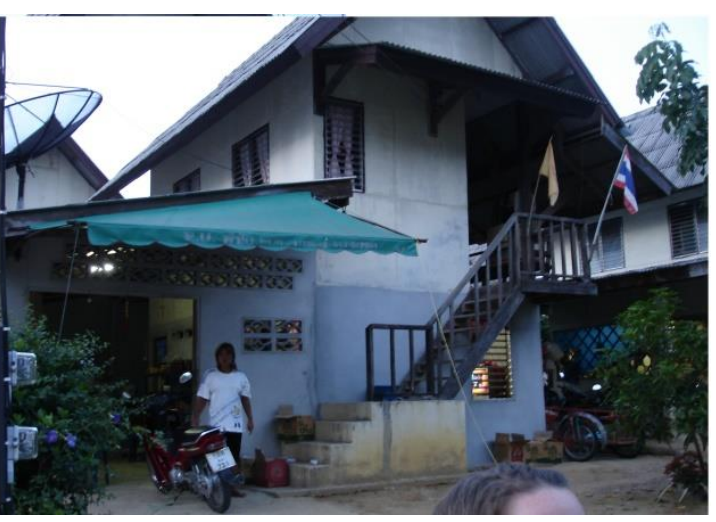

Figure 1: King's Housing Project, Phang Nga, Thailand. 
The project which costs the least empowered the most. What they received in the king's project were simple shelters, or core-houses. People knew how to build and did not need houses and the project did not turn them into passive recipients. They still needed shelter and support and those were precisely what they received. The provision of houses in Banda Aceh and Hambantota disempowered people at first. The king's project is a low-cost project that did not enrich politicians, bureaucrats, contractors, experts, and NGOs. The king provided the infrastructure, minimally, and people built individualized houses around the core, fulfilling their needs.

The king's project neither victimized the subjects, nor imposed a second disaster. It served the people well from the beginning. The subjects neither faced huge displacements, nor had problems connecting to infrastructure, as in Banda Aceh. They did not have to work hard to familiarize what was provided as in Hambantota. The project considered the people survivors and trusted their ability to build their own lives and environments. A small investment caused a huge change.

Sri Lanka needs a vision and a cadre of intellectuals who can develop grounded knowledge. The crucial lack that made its leaders and experts overlook the nation's strengths and advantages is the deficit mentality, personal gains, uncertainty in front of power and advantages, guided by the colonial frames of mind whether they are reproduced by modernity or globality. Most experts do not develop local knowledge, largely because they do not see much value in such knowledge. ${ }^{\mathrm{vi}}$

The larger development discourse has gone much further. (see Pieterse 2001; Escobar 1995) Muhammad Yunus received a Nobel Prize for his micro loan system in 2006, but there are much more effective interventions today, even in Bangladesh. There is an institution at Thiruvananthapuram devoted to the study of the Kerala Model. It conducts research, conferences, and produces publications. Bhutan has made the world consider its model: "happiness as development," reversing the trend to privilege means over goals. Similar developments can be found in Tibet. More importantly, experts look to a diverse array of places, outside of the West. Even the USA uses micro loans and the happiness Index.

In sum, there are alternatives to unsustainable and wasteful postcolonial development practices that cannot show many results. Infrastructure is integral to development and can empower people, but it is not a given; one must carefully plan for it. There is room for small change that could empower people and develop nations. (Hamdi 2004; Perera 2009) Such empowerment of people and the enhancement of their livelihoods require grounded thinking.

\section{In Sum}

Sri Lanka's rulers have squandered at least three opportunities to change the country's state of development, thus constructing it as a Third World nation. In regard to social indicators, Ceylon was a "developed" country at independence, and several foreign leaders were interested in following this model. In Sri Lanka, national leaders and experts did not recognize this possibility. Their (post)colonial perspective made them overlook the local strengths. Instead, they followed the development model propagated by the USA, reproducing the colonial development trajectory and later following proxies such as Singapore. The leaders thus transformed Sri Lanka into a Third World state, in the name of development.

When the capitalist world-economy was in crisis in the late-1960s through the 1980s, when the leaders of the system saved it through the construction of neoliberalism, Sri Lankan leaders reproduced the Third World status within the neoliberal structure by adopting structural adjustments. The more recent subjecting of the nation to China when the latter is vying to become a leading power is dangerous. Once the structures are formed, this dependency could last a century. Sri Lanka should stop playing the victim and step up to the role of survivor, taking its fate into its own hands. 
This requires the development of a grounded knowledge. The situation calls for the nation to move away from party, family, and other types of sectarian thinking to national thinking. As much as learning from other experiences abroad, the experts could also learn from Sri Lanka. The best way to incorporate local knowledge in the development process is to work with ordinary people.

Here I refer not to collecting data about these people using external frameworks, but to respecting and making use of people's worldviews and life journeys. (cf. Perera and Tang 2013) The most sensible approach to respect people's views is not to represent them but to help people empower themselves at an everyday level by supporting their own life journeys but balancing with regulatory and managerial responsibilities of the state.

Building on these ideas, I developed for discussion a set of deprivations that the Sri Lankan state can try to eliminate. I wish to leave that discussion for the last article of the issue.

Note: An earlier version of this paper was delivered as keynote to the 14th Centre for Poverty Analysis (CEPA) Symposium on Infrastructure and Development, Colombo, November 23-4, 2015. I wish to thank Vijay Nagraj and Mansi Kumarasiri for their help and Udan Fernando for the invitation.

\section{REFERENCES}

Bhabha, Homi K. (1994) The Location of Culture, London and New York: Routledge. $\square$

Boggs, Grace Lee (2012). The Next American Revolution: Sustainable Activism for the Twenty-First Century. Berkeley, CA: University of California Press.

Braudel, Fernand. 1985: Civilization and Capitalism. Vol. III: The perspective of the world. London: Fontana.

Escobar, Arturo. (1995) Encountering Development: The Making and Unmaking of the Third World. (Princeton: Princeton University Press, 1995).

Fernando, Nishara. (2015). Social Mobility and Class Formation: An Analysis of the Housing Market in Colombo. Paper presented to the CEPA Conference 2015 Nov 27, Colombo, Sri Lanka.

Frank, André Gunder (1976). Dependent Accumulation and Underdevelopment (New York: Monthly Review Press, 1979)

Goonatilake, Susantha. (1984) Aborted Discovery: Science and creativity in the Third World, London: Zed Books.

Hamdi, Nabeel. (2004) Small Change: About the art of practice and the limits of planning in cities, Sterling, VA: Earthscan.

Harvey, David. (2005). A Brief History of Neoliberalism. Oxford: Oxford University Press.

List of countries by income inequality, at https://en.wikipedia.org/wiki/List_of_countries_by_ income_equality, accessed on May 10, 2016

List of Countries by Suicide Rate. (2016) Wikipedia, found at: <https://en.wikipedia.org/wiki/List_of_ countries_by_suicide_rate> Accessed on May 21, 2016.

Nandy, Ashis. (2004). “The Beautiful, Expanding Future of Poverty: Popular Economics as a Psychological Defence" Economic and Political Weekly, Vol. 39, No. 1 (Jan. 3-9): pp. 94-99.

Perera, Nihal (2016) People's Spaces: Coping, Familiarization,Creating. New York: Routledge. 
Perera, Nihal. (1999) Decolonizing Ceylon: Colonialism, Nationalism, and the Politics of Space in Sri Lanka. Oxford University Press

Perera, Nihal (2005) Importing Problems: The Impact of a Housing Ordinance on Colombo. Arab World Geographer, 8, 1-2 (Summer): 61-76

Perera, Nihal. (2009) "Asian Urbanization and Planning: Viewing the production of space from the spaces of production," Bhumi 1, 2: 1-24.

Perera, Nihal. (2010) "When Planning Ideas Land: Mahaweli’s people-centered approach" in P. Healey and R. Upton (eds.) Crossing Borders: International exchanges and planning practices, New York: Routledge, 141-72.

Perera, Nihal. and Tang, W.S. (2013) Transforming Asian Cities: Intellectual impasse, Asianizing space, and emerging translocalities, New York: Routledge.

Perkins, John (2004) Confessions of an Economic Hit Man. Berrett-Koehler Publishers. CA: Oakland.

Pieterse, Jan Nederveen, 2001. Development Theory: Deconstructions/ Reconstructions. New Delhi: Vistaar.

Rostow, Walt W. (1960) The Stages of Economic Growth, a Non-Communist Manifesto. Cambridge Eng.: University Press.

Sebastian, Sheryl. 2016. What Led to the Decline of the Matrilineal Society in Kerala? Feminism in India.com. http://www.feminisminindia.com/2016/09/01/decline-matrilineal-society-kerala/\#.VX_-pMrLR3 Retrieved on Sep 23, 2016.

Sen, Amartya. 1999. Development as Freedom. New York: Knopf.

Strange, Susan (1986) Casino Capitalism. Oxford: Basil Blackwell.

Wallerstein, Immanuael. 1979: The Capitalist World Economy: Essays by Immanuel Wallerstein. Cambridge, UK: Cambridge University Press.

Wallerstein, Immanuael. 2004: World Systems Analysis: An introduction. Durham, NC: Duke University Press.

Yapa, Lakshman. (1998) The Poverty Discourse and the Poor in Sri Lanka. Royal Geographical Society. 23: 95-115.

\footnotetext{
${ }^{\mathrm{i}}$ Niyaras are pathways in between rice-paddy fields.

ii The situation seems to have peaked, but the improvements are marginal.

iii The lead project of the 1977 government, the Mahaweli Project opted to maximize the production of rice and hydropower through the construction of dams across the longest river in Sri Lanka, Mahaweli River, and channeling water to dry areas of the country, producing hydropower along the way. Megapolis is the lead project of the current (2015) government; it opts to redevelop Colombo, but redefined as the Western Province.

${ }^{\text {iv }}$ When a relative of mine with bad knees approached an orthopedic surgeon, he who checked x-rays and talked with the patient for two minute told that he can do a knee replacement for SLR 7 Lakhs; both for 14. Just like that. This is not abnormal.

${ }^{\mathrm{v}}$ When I presented an earlier version of this paper at the CEPA conference of 2015, a well-known Professor simply dismissed these arguments as old. However, only "information and facts" get old and outdated, not the knowledge. The theories employed here are "old," but this argument examines the old material from newer perspectives, using the threshold, the vantage point, and postcolonial theories. The conclusions are radically different from the well-known ones. Evidently, the "old" discourse has consumed the experts.

${ }^{v i}$ See Transforming Asian Cities (Perera and Tang 2013) for an elaboration of three factors: the focus, the framework, and the vantage point that needs addressing.
} 